\title{
POSITION OF ADOPTED CHILDREN IN THE DISTRIBUTION OF HERITAGE PROPERTY IN INDONESIA
}

\author{
Cucuk Kristiono \\ Police Educational center of the Binmas unit \\ kanit3oye@gmail.com
}

\begin{abstract}
Adoptions are included in the category of legal acts, the which resulted in the rightsand obligations of the parties. In the Burgelijk Weetboekand the compilation of Islamic law, are differences in theregulations about how the positions Adopted child to the adoptive parents. It is implicated in the process of inheritance. Adopted inheritance of the children in accordance with Islamic Law Compilationused was was borrowed, while the Burgelijk Wetboeek, inheritthe same Adopted children with legitimate children
\end{abstract}

Keywords: Adopted Child, Was Borrowed, Inhewritanse.

\section{A. INTRODUCTION}

Constitutionally, education is one of the fundamental elements set out in Article 28 and 31 of the 1945 Constitution. Therefore, it requires the government to respect, fulfill and protect the public in accessing educational resources, information and technology. ${ }^{1}$ To achieve the condition of society who live healthy and prosperous in the future. ${ }^{2}$

Foster child is a part of all tumpuhan and expectations of both parents (father and mother) as the successor of life. Having a child is the purpose of their marriage to connect descent and preservation of wealth. Having a child is the pride of the family. However, according to these goals sometimes can not be achieved in line with expectations. Some spouses, not a few of them have difficulty in obtaining offspring. Being a desire to have children seemed so great. so then in between they also exist that adopt a child ${ }^{3}$.

Adoption is divided in two senses: first, the adoption in a broad sense. It raises nasab relationships that exist between the rights and obligations should own child against the parents themselves. second, in the sense of adoption is limited. namely the adoption

\footnotetext{
${ }^{1}$ Mashdurohatun, Anis. "Constructing And Developing The Social Function Principles In Utilising Copyright Products Related To The Fundamental Rights." South East Asia Journal of Contemporary Business, Economics and Law 7, no. 4: 2289-1560.

2 Muallim, M. H., Gunarto, G., \& Mashdurohatun, A. (2017). RECONSTRUCTION OF THE WASTE MANAGEMENT LAW BASED ON WELFARE VALUE. The 2nd Proceeding "Indonesia Clean of Corruption in 2020". P.616.

${ }^{3}$ Thaib Dahlan, dkk., 2010, Teori dan Hukum Konstitusi, Rajawali Press, Jakarta, p.43
} 
of others into their own family and the relationship between the adopted child and the parents who raised only limited social connections only ${ }^{4}$.

In Indonesia, there are three legal system and regulate the issue of adoption which Justice theory postulates dignified departure from the system; working towards the goal, that is justice with dignity. ${ }^{5}$ The third is the legal system of Islamic law, customary law and Western law. For a while the discussion of customary law and Western law did not we mention here, but rather concentrated to Islamic law.

Islamic religion is basically not prohibit the practice of adoption, so far not affected and do not alter the relationship nasab or descent between the child and his biological parents, Practice adoptions will be prohibited when this has resulted in the release of the adopted child of a relationship nasab or descent between the child and his biological parents own and went in nasab relationship with his adoptive parents. Prohibition of adoption in the sense of actually making a biological child is based on the Word of Allah. In Surah Al-Ahzab (33) verses 4 and 5.

He made your adopted sons as your birth child (myself). Such a dimulutmu are yours alone. 5. Call them (adopted children it) by (using) the name of their fathers; That is more equitable in the sight of God, and if you do not know their fathers, then (they call an as) your brothers in religion ${ }^{6}$. Adoption allowed Islamic law also has no effect in law of inheritance. Thus Islam does not make an adopted child as the cause of the heir-inherited rights between the adopted child with the adoptive parents ${ }^{7}$.

\section{B. DISCUSSION}

\section{Adopted Children and Inheritance}

a. Definition of adopted child

Definition of adopted children in the language or etymology can be interpreted as follows: First, the adopted child in Arabic called "tabanny" is a habit at the time of ignorance and the beginning of Islam that if a lifting other people's children as sons, the operator from the laws in force on the biological

\footnotetext{
${ }^{4}$ Soeroso R, 2001, Perbandingan Hukum Perdata, Sinar Grafika, Jakarta, p. 61

${ }^{5}$ Muhammad Khambali, Teguh Prasetyo, Sri Endah Wahyuningsih, Reconstruction of Criminal Procedural Law (KUHAP) about the Detention Based on Justice, The 2nd Proceeding "Indonesia Clean of Corruption in 2020, 2017/5/23.p.513.

${ }^{6}$ H.Ahmad Kamil dan H.M Fauzan, 1991, Hukum perlindungan dan pengangkatan anak diindonesia, Gema Insani Press, Jakarta, p.46

7 Mahmud Yunus, 1972, kamus arab indonesia, Hidakarya Agung, Jakarta, p.27
} 
child and according to Muhammad Yunus mean by taking a foster child, whereas in the dictionary Munjid interpreted 'ittikhhadzahu ibnan', ie make as a child. Both foster child who comes from the word " luqata "which means taking a foundling means the removal of minors found on the street and not known descendants ${ }^{8}$.

Adoption is also known as adoption comes from the English language is "adoptie" or "adopt". The sense in the Dutch language dictionary according to law is the removal of a child to be used as biological children. In line with the adopted child meaning, KHI (Compilation of Islamic Law) and then enter the legal effect of the adoption by Mu'thi Artho, namely ${ }^{9}$ :

1) Switch maintenance responsibility of daily living, education expenses and so forth of the parents of origin to the adoptive parents.

2) Adoption not disconnect blood / nasab between the adopted child with his biological parents so that the mahram relationship remains valid and inherit each other.

3) Adoption does not cause blood relations / nasab between adopted children with adoptive parents.

Similarly, an elaboration of Article $171 \mathrm{KHI}$ in letter $\mathrm{h}$, which says that the adopted child is a child in the maintenance of everyday life, educational expenses and so shift of responsibility from the parents of origin to the adoptive parents based on the decision of the Court; if you see that sense, it means also that the adopted child here has become part of the family of the parents who raised it. As part of the family (kids), he is entitled to get the love and affection of parents like the others

b. understanding inheritance

Inheritance is the rules on transfer ownership of the person who has died to his heir ${ }^{10}$. In other terms also called fara'idh inheritance, which means that certain parts that are divided according to the religion of Islam to all those who deserve it. ${ }^{11}$

Besides the notion of inheritance is also contained in Article 171 paragraph (a) KHI, which reads: "The law of inheritance is the law governing

\footnotetext{
${ }^{8}$ Muderis Zaini, 2002, Adopsi Suatu Tinjauan Dari Tiga Sistem Hukum, Sinar Grafika, Jakarta, p.14-15

${ }^{9}$ Soebekti, 1995, Kamus Hukum, Aneka Ilmu, Semarang, p.18

10 Mu'thi Artho, "Pengangkatan anak menurut Hukum Islam," makalah, (Perpustakaan Pengadilan Agama Bantul), p.22

${ }^{11}$ H. Abdurrahman, 2007, Kompilasi Hukum Islam, Akamedika pressindo, Jakarta, p.5
} 
the transfer of ownership rights to inheritance (tirkah) heir, determine who has the right to be the heirs and how their share. "In the Islamic legal literature encountered some terms to name the Islamic inheritance law as faraid, Jurisprudence Mawaris and inheritance law. Differences in naming this happened due to differences in the direction of the main points made in the discussion. In addition to the second term, the word commonly used is faraid. Some legal experts in Indonesia do not use the naming uniformly. For example, Wirjono Prodjodikoro, using the legal term legacy. Hazarin, using the term inheritance law $^{12}$.

Discussion on inheritance law here simply drawn to the adopted children, as well as the above background, it is no more demand for the right of adopted children than just getting affectionate adoptive parents, as well as fulfilling all the obligations of children to parents. However, love can be realized even then not only morally, but also realized materially. As for the adopted children there needs to be an affirmation that in accordance with the provisions of Islamic law adopted children did not inherit his adoptive parents. However, the adopted child entitled to a share of the treasure adoptive parents through other procedures. Namely a way through was borrowed. As it has been disclosed in the agreement in the form of $\mathrm{KHI}$ that ${ }^{13}$ : "Against the foster child who did not receive a testament given was borrowed as much as $1 / 3$ of the estate adoptive parents."

\section{Adopted Position Of Treasure Inheritance In Islamic Law}

Islamic law or Sharia Islam is a universal Shari'ah, the Quran as a fundamental principal in Islamic law contains provisions which complete. This is the cover to all forms of human behavior that will emerge in the future akaan come. All behavior that can be measured with the norms and sizes guidance contained in the Quran. Thus any legal lines that will be created by humans can be measured according to the Quran.

There are three approaches to understanding Islam or Shari'a, ie with Nakli or traditional approach, the approach aqli or reasonable and Kashfi or mystical

\footnotetext{
${ }^{12}$ Beni Ahmad Saebai, 2009, Fiqh Mawaris, Pustaka Setia, Bandung, p.19

${ }^{13}$ Amir Syarifudin, 2005, Hukum Kewarisan Islam, Prenada Media, Jakarta, p. 42
} 
approach. The third approach has existed since the time of the prophet Muhammad, and on articles used by later scholars ${ }^{14}$.

\section{Analysis of Inheritance Law Adopted According to Classical Scholars}

Opinion adopted children according to the classical scholar does not get inheritance rights, because there is no blood relationship or marriage, but KHI signaled by giving was borrowed against adopted children. Which carry out the will according to Imam four madzhab, the original law sunnah based word yuridu (Arabic) in the hadith narrated by Imam Malik of An-Nafi as follows: "There is no right for a Muslim who has something (juridical) want diwasiatkannya which to spend the night two night, then it shall be written wills for him ". Priests four schools found intestate should sunna with reason, because there is no proposition that says the Prophet Muhammad and his companions do so. However testament to switch obligatory, permissible and forbidden even makruh depending on the goals and objectives.

\section{a.Analysis of Inheritance Law Adopted By Organization}

1) Muhammadiyah

Described in the Qur'an:

i. Allah has not made for a man two hearts in their sockets; has He made your wives whom you zhihar as a mother, has He made your adopted sons as your birth child (myself). Such a dimulutmu are yours alone. and Allah is telling the truth and He shows the (right).

ii. Call them (adopted children it) by (using) the name of their fathers; That is more equitable in the sight of God, and if you do not know their fathers, then (they call an as) your brothers in religion and Your protector. and there is no sin for you in what you mistake him, but (which is sin) any willful heart. and Allah is Forgiving, Merciful.

The word Zhihar is a husband to his wife: Haram your back to me like the back of my mother or other words of similar meaning. is customary for the Arabs of Ignorance that when he spoke thus to His Wife So She was illegitimate for him forever. but after Islam came, then the Haram forever be abolished and the wives of the back lawful for him to pay kaffarat (fines). Maula is a slave who has been freed, or one that has been used as an adopted child, foster child as Salim Huzaifah, called

\footnotetext{
${ }^{14}$ Eman Suparman, 2005, Hukum Waris Indonesia Dalam Perspektif Islam, Adat dan BW, Bandung, p.20
} 
Maula Huzaifah ${ }^{15}$.

From the verses of the Quran above, obtained confirming that the adopted child should not be didaku and equated as biological children, resulting in the division of inheritance, adopted children who do not have a relationship nasab or blood relationship with his adoptive parents can not inherit each other. In other words, the adopted child does not inherit the estate left by his adoptive parents, and vice versa adoptive parents do not inherit the legacy of his adopted son. However, in Islamic Law Compilation position adopted children in the division of inheritance is mentioned as a recipient of a will; as mentioned in Article 209 paragraph (2): "Against the foster child who did not receive a testament given was borrowed as much as $1 / 3$ treasure adoptive parents". On the basis of these provisions,

2) Nahdlatul Ulama

Nahdlatul Ulama (NU) in the General Assembly of Ulama in Situbondo, East Java on December 21, 1983 also set a fatwa on Adoption. In his fatwa, NU clerics declared that "Lifting other people's children to be treated, used, recognized as their own children the law is illegal." As a legal basis, NU scholars quote the hadith the Prophet ${ }^{16}$. "Anyone claiming to someone else as a father, and he knows that the person is not the father, then heaven is forbidden to him." Qatada said, whoever should not say "Zaid is the son of Muhammad". (Khazin, the Section Vi p 191) "Adoption can not make children the equal of his own children in nasab, mahram or inheritance rights," said NU clerics in his fatwa. So the adopted child is not entitled to inheritance ${ }^{17}$.

\section{Analysis of Inheritance Law Adopted By Author}

Talk inheritance rights issues adopted children, there is no proof that allows for the inheritance rights of the adopted child, foster child but would that still be

\footnotetext{
${ }^{15}$ www.stain-papua.ac.id/jurnal/jurnal/2011/70-washiyat-wajibah-menurut-fiqih-dan-perundang-undangandi-indonesia.html

${ }^{16}$ www.id-id.facebook.com/note.php?note id $=209463365759114$

17 www.republika.co.id/berita/ensiklopedia-islam/fatwa/10/06/13/119639-mengadopsi-anak-menurut-hukumislam
} 
given on heritage treasures adoptive parents. Namely by way of giving him the will as has been disclosed in the books of Fiqh Mawaris ${ }^{18}$ (Beni Ahmad Saebani, 2009: 346): will be directed to siapapunsesuai with the will of the intestate, even to the unborn baby was permissible. It is thus according to the authors there is no obstacle foster child may be given by way of a will, for the adopted child is meritorious who had cared for him even adoptive parents who had been running the family economy.

\section{CONCLUSION}

Adopted children should not be claimed and equated as biological children, resulting in the division of inheritance, adopted children who do not have a relationship nasab or blood relationship with his adoptive parents can not inherit each other. In other words, the adopted child does not inherit the estate left by his adoptive parents, and vice versa adoptive parents do not inherit the legacy of his adopted son. However, in Islamic Law Compilation position adopted children in the division of inheritance is mentioned as a recipient of a will; as mentioned in Article 209 paragraph (2): "Against the foster child who did not receive a testament given was borrowed as much as $1 / 3$ treasure adoptive parents". On the basis of these provisions, then if two adopted children as mentioned in this question.

\section{BIBLIOGRAPHY}

Abdurrahman, 2007, Kompilasi hukum Islam, Akamedika pressindo, Jakarta.

Ahmad Kamil dan H.M Fauzan, 1991, Hukum perlindungan dan pengangkatan anak diindonesia, Gema Insani Press, Jakarta.

Amir Syarifudin, 2005, Hukum Kewarisan Islam, Prenada Media, Jakarta.

Beni Ahmad Saebai, 2009, Fiqh Mawaris, Pustaka Setia, Bandung.

Eman Suparman, 2005, Hukum Waris Indonesia Dalam Perspektif Islam, Adat dan $B W$, Bandung.

${ }^{18}$ http://grupsyariah.blogspot.com/2012/04/makalah-kedudukan-anak-angkat-terhadap.html 
Khambali, M., Prasetyo, T., \& Wahyuningsih, S. E. (2017). Reconstruction of Criminal Procedural Law (KUHAP) about the Detention Based on Justice. The 2nd Proceeding "Indonesia Clean of Corruption in 2020".

Mashdurohatun, Anis. "Constructing And Developing The Social Function Principles In Utilising Copyright Products Related To The Fundamental Rights." South East Asia Journal of Contemporary Business, Economics and Law 7, no. 4: 22891560.

Mu'thi Artho, "Pengangkatan anak menurut Hukum Islam," makalah, (Perpustakaan Pengadilan Agama Bantul).

Mahmud Yunus, 1972, Kamus Arab Indonesia, Hidakarya Agung, Jakarta.

Muallim, M. H., Gunarto, G., \& Mashdurohatun, A. (2017). RECONSTRUCTION OF THE WASTE MANAGEMENT LAW BASED ON WELFARE VALUE. The $2 n d$ Proceeding "Indonesia Clean of Corruption in 2020".

Muderis Zaini, 2002, Adopsi Suatu Tinjauan Dari Tiga Sistem Hukum, Sinar Grafika, Jakarta.

Soebekti, 1995, Kamus Hukum, Aneka Ilmu, Semarang.

Soeroso R, 2001, Perbandingan Hukum Perdata, Sinar Grafika, Jakarta.

Thaib Dahlan, dkk., 2010, Teori dan Hukum Konstitusi, Rajawali Press, Jakarta.

www.stain-papua.ac.id/jurnal/jurnal/2011/70-washiyat-wajibah-menurut-fiqih-danperundang-undangan-di-indonesia.html

www.id-id.facebook.com/note.php?note id=209463365759114

www.republika.co.id/berita/ensiklopedia-islam/fatwa/10/06/13/119639-mengadopsianak-menurut-hukum-islam

http://grupsyariah.blogspot.com/2012/04/makalah-kedudukan-anak-angkatterhadap.html 